\title{
Subcritical and Supercritical Operation of Innovative Thermal Mechanical Refrigeration System
}

\section{Abstract \\ Around $17 \%$ of the global generated energy is consumed for residential, commercial, and transportation refigeration. The current cooling technologies utilize refrigerants with high Ozone Depletion and Global Warming Potentials. Furthermore, the current technologies are expensive alongside with toxicity and flammability hazards. On the other side, energy produced by combustion of fossil fuels result in substantial amounts of waste heat. So, it is necessary to develop new refrigeration technologies that utilize waste heat as a source of energy with eco- friendly refrigerants with zero ozone depletion potential and zero global warming potential. Also, the Thermal Mechanical Refrigeration (TMR) technology improves the energy efficiency of the source of waste heat system and minimizes the emissions of the carbon dioxide $\left(\mathrm{CO}_{2}\right)$. In this study, a novel thermo-mechanical refrigeration system is proposed. It operates with low-grade energy sources (such as waste heat) at temperature range of $60^{\circ} \mathrm{C}$ to $100^{\circ} \mathrm{C}$. Furthermore, it has the advantage of working with low-frequency driver-compressor unit, which eliminates noise and increases its lifetime. Moreover, the TMR system is adaptable to commercial, transportation and residential refrigeration applications.}

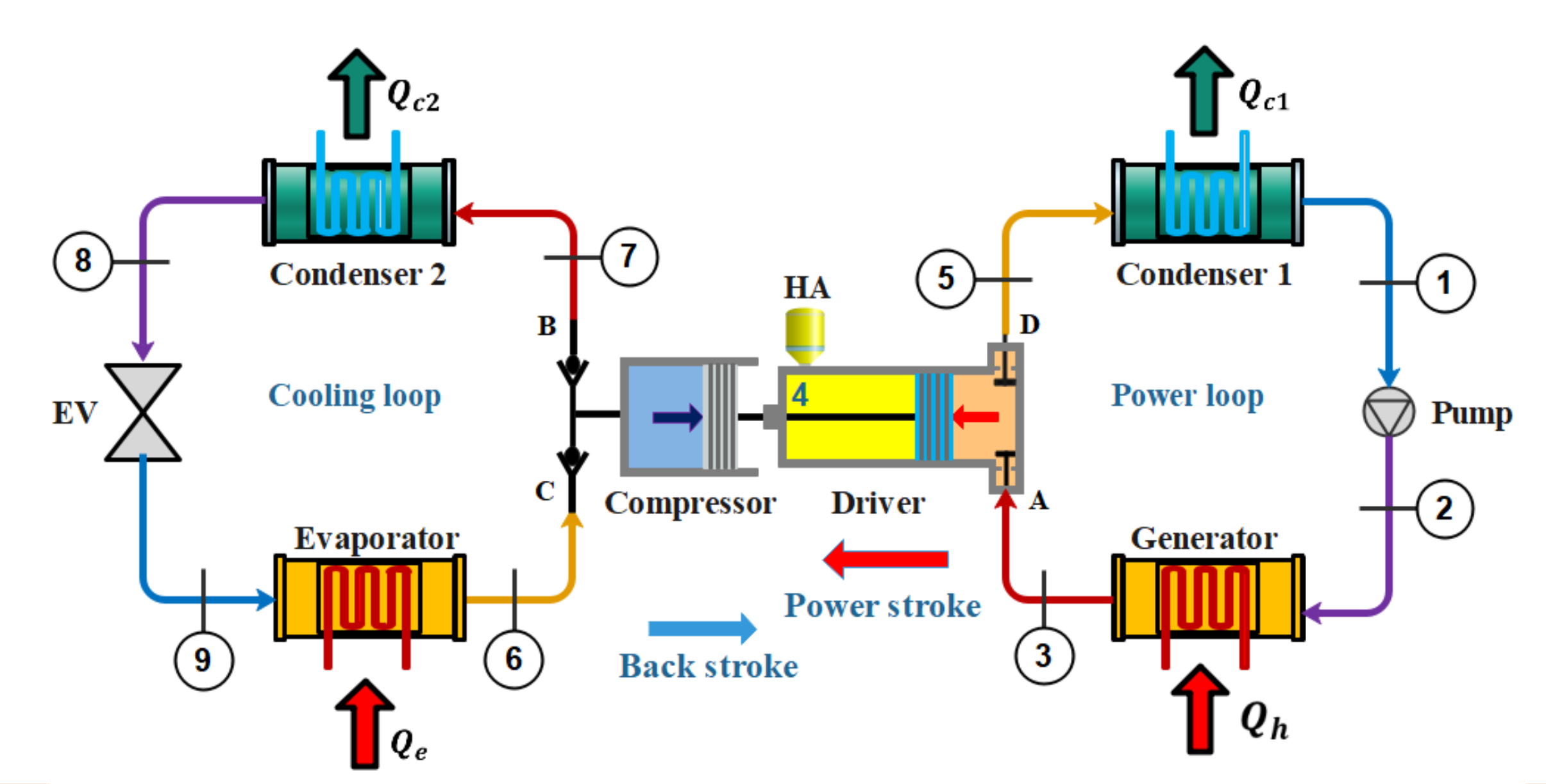

Figure 1. Schematic diagram of the regenerative thermo-mechanical refrigeration system.

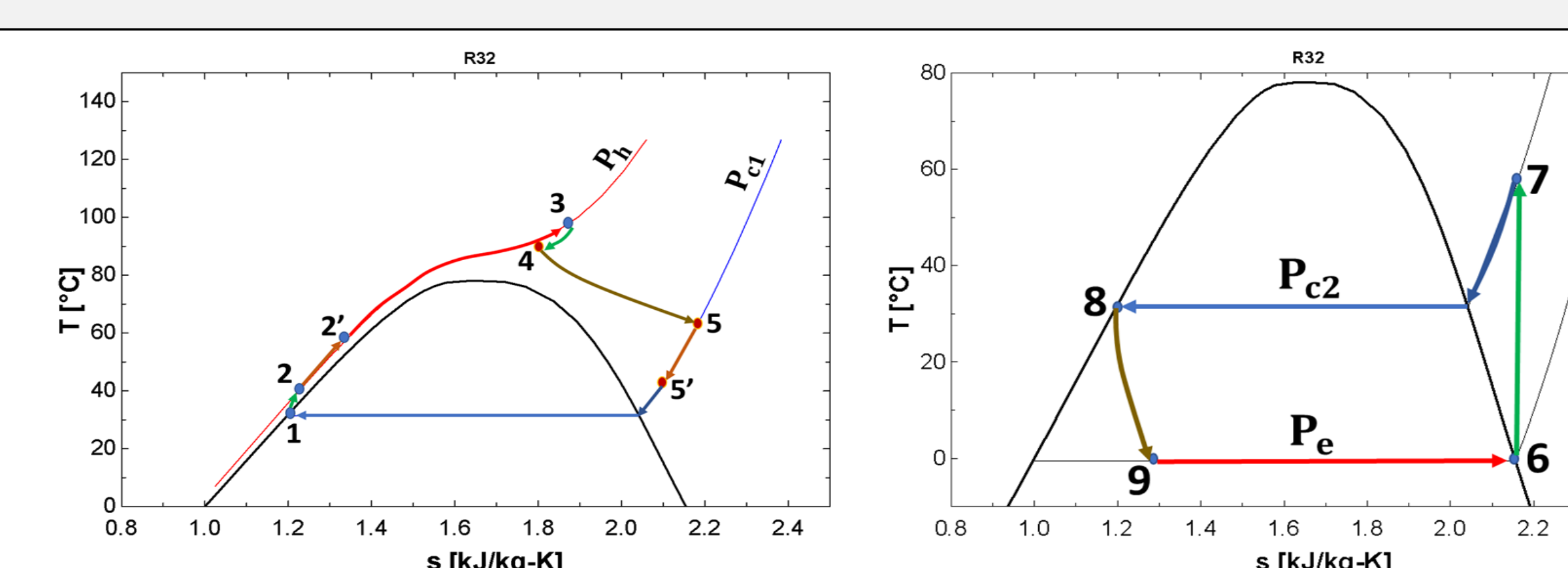

Figure 3. T-s diagrams of the power and cooling loops in supercritical mode

\section{Results}

At heat source temperature from $70{ }^{\circ} \mathrm{C}$ to $100{ }^{\circ} \mathrm{C}$, the subcritical mode is more advantageous than supercritical mode. In this range, using R707 in power loop with R32 in cooling loop provides maximum power efficiency of 7.8\%, (See Figure 6).

At heat source temperature higher than $100{ }^{\circ} \mathrm{C}$, the supercritical mode is more advantageous than subcritical mode. In this range, using R32 in power and cooling loops provides power efficiency of $10.8 \%$ (with regenerator) and 9.6\% (without regenerator).

The size of the expander-compressor unit depends on four factors: pressure difference between the higher and lower pressures of the power cycle, the evaporator temperature, the condenser temperature and the cooling capacity of the cooling cycle.

Systematic steps a

Over the design range, the expander diameter range varies from $45 \mathrm{~mm}$ to $65 \mathrm{~mm}$ and the compressor diameter range varies from $72 \mathrm{~mm}$ to $80 \mathrm{~mm}$ for a cooling capacity of $2 \mathrm{~kW}$ to $6 \mathrm{~kW}$ (See Figure 7)

\section{Comparison}

\begin{tabular}{|c|c|c|c|c|c|}
\hline & TMR systems & ORC systems & $\begin{array}{l}\text { Absorption } \\
\text { systems }\end{array}$ & Ejector systems & $\begin{array}{l}\text { Thermo-electric } \\
\text { systems }\end{array}$ \\
\hline $\begin{array}{l}\text { Range of heat } \\
\text { source temperature }\end{array}$ & $60-100^{\circ} \mathrm{C}$ & $100-300^{\circ} \mathrm{C}$ & $90-220^{\circ} \mathrm{C}$ & $60-160^{\circ} \mathrm{C}$ & N.A \\
\hline Main advantages & $\begin{array}{l}\text { - Low-grade heat } \\
\text { source } \\
\text { - Simple design (low } \\
\text { cost) } \\
\text { - Flexible capacity } \\
\text { - Stable performance }\end{array}$ & $\begin{array}{l}\text { - Proven } \\
\text { technology } \\
\text { - Electrical } \\
\text { output }\end{array}$ & $\begin{array}{l}\text { Economic for } \\
\text { large } \\
\text { commercial } \\
\text { applications }\end{array}$ & $\begin{array}{l}\text { - Simple design } \\
\text { (low cost) }\end{array}$ & $\begin{array}{l}\text { - No moving parts. } \\
\text { - No working fluids }\end{array}$ \\
\hline Main drawbacks & $\begin{array}{l}\text { - Moving parts (pistons, } \\
\text { valves) }\end{array}$ & $\begin{array}{ll}\text { - High cost } \\
\text { - Low expander } \\
\text { efficiency }\end{array}$ & $\begin{array}{l}\text { - Large size } \\
\text { - Limited cooling }\end{array}$ & $\begin{array}{l}\text { - Fluctuation at } \\
\text { off-design } \\
\text { conditions }\end{array}$ & $\begin{array}{l}\text { - Very high cost } \\
20,000-30,000 \$ / \mathrm{kW}\end{array}$ \\
\hline
\end{tabular}

\section{Conclusions.}

- A novel thermo-mechanical refrigeration system is introduced.

- The proposed system able to operate with low-grade energy with temperature range of $60^{\circ} \mathrm{C}$ to $100^{\circ} \mathrm{C}$.

- It can work with low-frequency which eliminate noise and increase the service time.

- Thermodynamic investigation of the system performance under subcritical and super-critical mode is applied and published.

It is important to improve the control mechanism of the valves of the proposed system. It may be applied mechanically as shown in Figure 8.

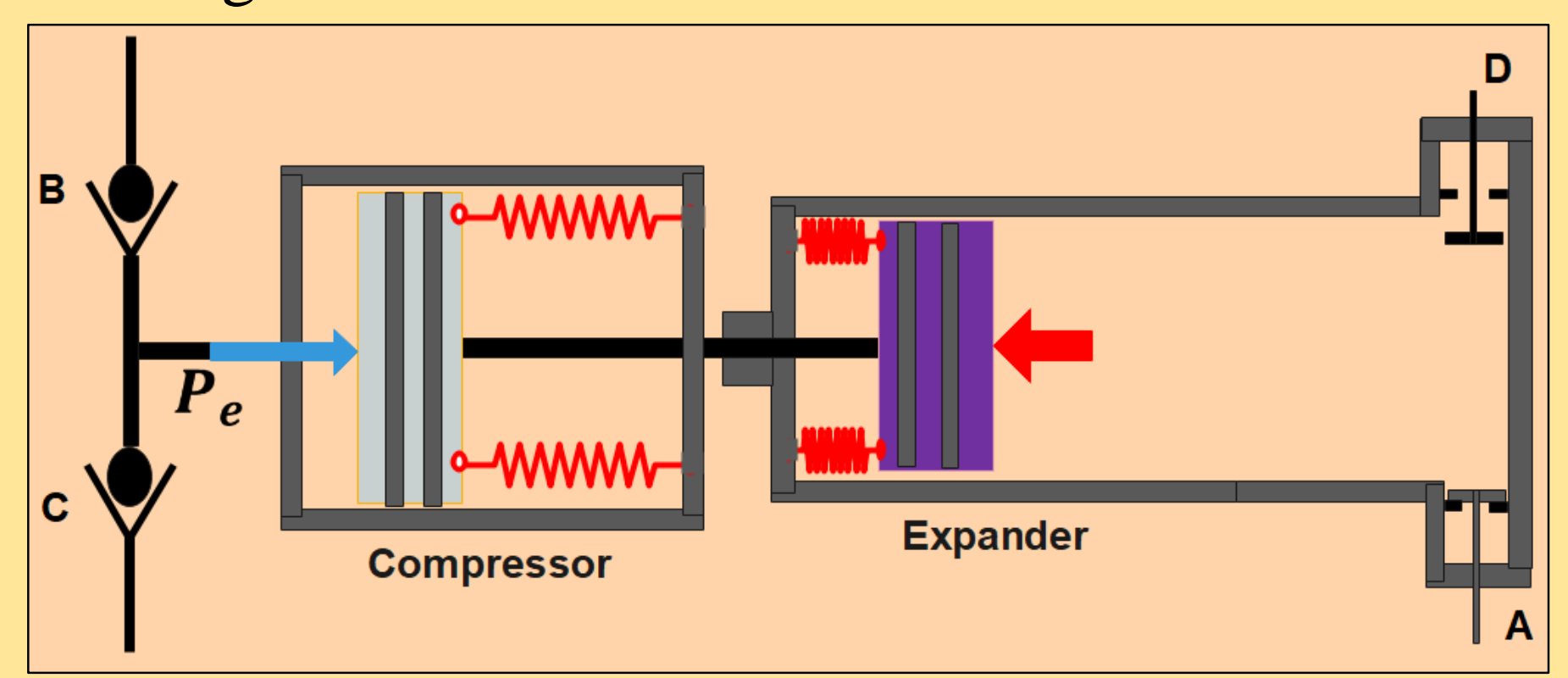

Figure 8. Mechanical valve control mechanism to be investigated in future work.

\section{ntroduction}

Refrigeration and air-conditioning systems

much higher than $100^{\circ} \mathrm{C}[2]$

It is necessary to develop cooling system that has: very low effects on the A nove

A novel isobaric thermal mechanical refrigeration (TMR) system has been B.V. company [4].

.

-

It can be designed for various capacities and demands.

Its performance is stable with the variation of the heat source temperature and/or with the variation of the cooling load.

Benefits of the study
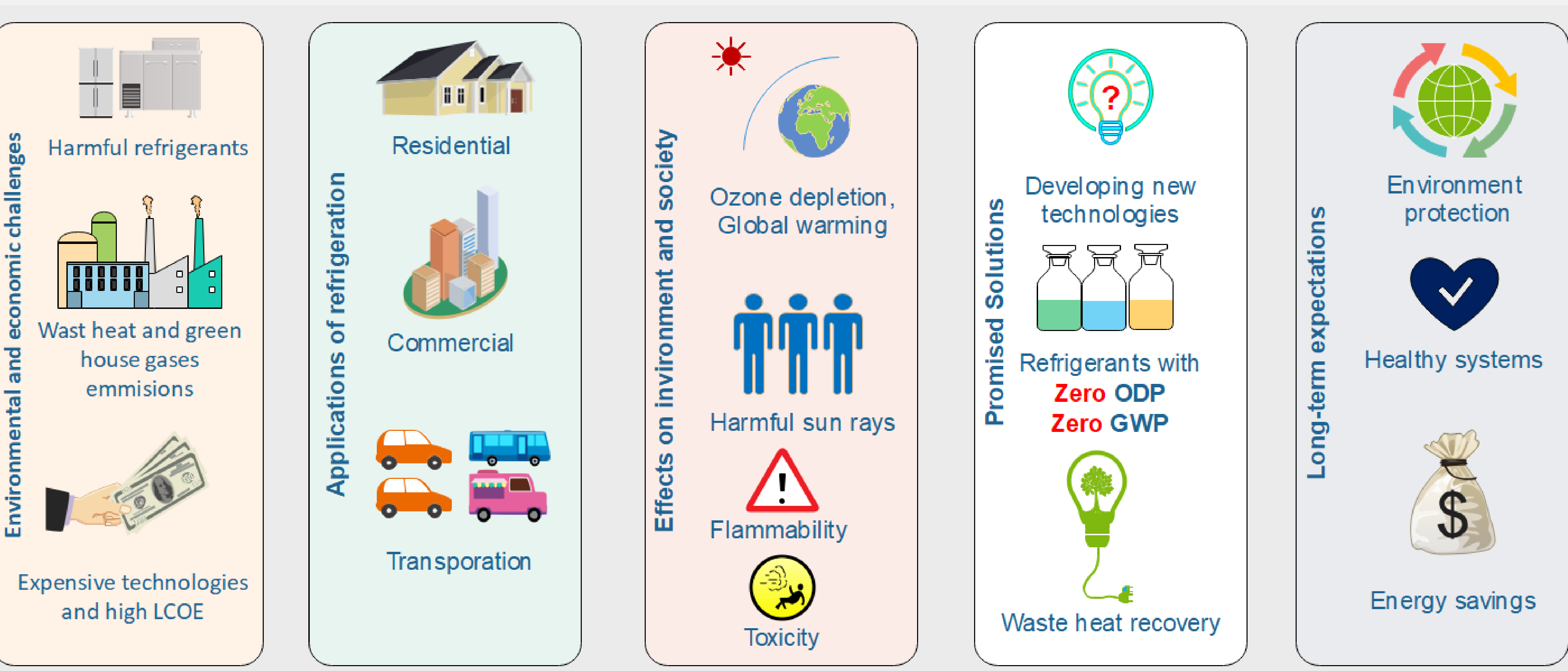

Figure 2. Challenges, applications, effects, and proposed solutions of the refrigeration technologies.
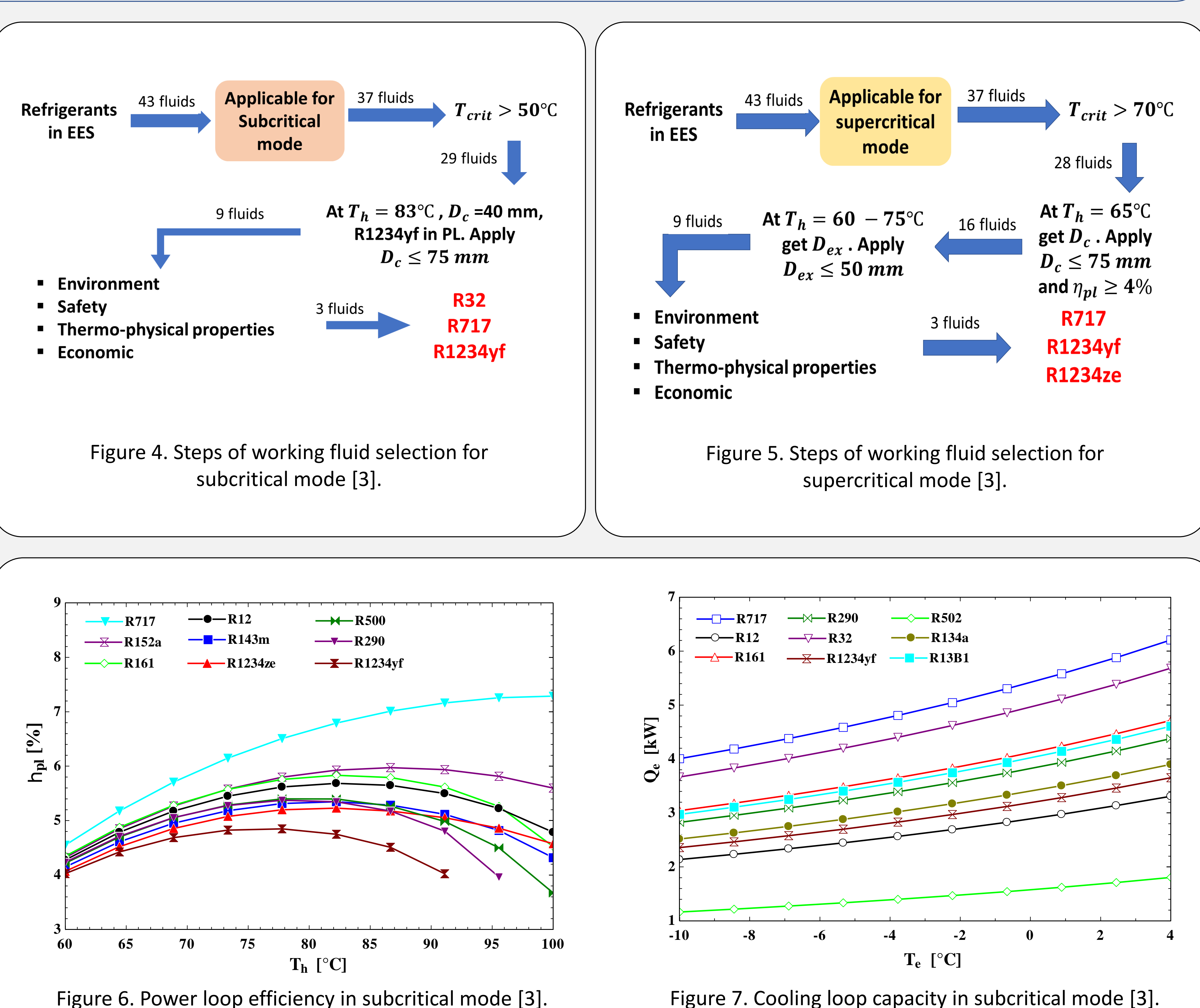

\section{Acknowledgement}

This work was made possible by NPRP-S grant \# [11S-1231-170155] from the Qatar National Research Fund (a member of Qatar Foundation). The findings herein reflect the work, and are solely the responsibility, of the authors.

\section{References}

[1] S. S. Refaat and H. Abu-Rub, "Residential load management system for future smart energy Work. Smart Grid Renew. Energy, SGRE 2015, pp. 1-6, 2015, doi:10.1109/SGRE.2015.7208735.

A. K. Sleiti, W. A. Al-Ammari, and M. Al-Khawaja, "Review of innovative approaches
grade heat," Int. J. Energy Res., vol. 2020, pp. 1-31, 2020, doi: 10.1002/er.5556.

3] A. K. Sleiti, M. Al-Khawaja, and W. A. Al-Ammaria, "A combined thermo-mechanical refrigeration system with isobaric expandercompressor unit powered by low grade heat - Design and analysis," Int. J. Refrig., 2020, doi: 10.1016/j.jijefrig.2020.08.017.

(4) M. Glushenkov, A. Kronberg, T. Knoke, and E. Y. Kenig, "Lsobaric expansion engines: New opportunities in energy conversion for heat enghes, pumps and compressors," Energies, 2018, doi: 10.3390/en11010154.

A. K. Sleiti, W. A. Al-Ammaria, and M. Al-Khawaja, "A novel solar integrated distillation and cooling system - Design and analysis," Sol. En. K. Sy, vol. 206, pp. 68-83, 2020, doi: 10.1016/J.solener.2020.05.107.

M. Shublaq and A. K. Sleiti, "Experimental analysis of water evaporation losses in cooling towers using filters," Appl. Therm. Eng., vol. 175, no. April, p. 115418, 2020, doi: 10.1016/j.applthermaleng.2020.115418. 016/j.rser.2016.11.150. 